\title{
Care management and nursing governance in a maternity ward: grounded theory
}

\author{
Gerência do cuidado e governança de enfermagem em uma maternidade: teoria fundamentada \\ Administración del cuidado y gobernanza de enfermería en una maternidad: teoría fundamentada
}

\section{Fernanda Hannah da Silva Copelli', Roberta Juliane Tono de Oliveira', José Luís Guedes dos Santos', Aline Lima Pestana Magalhães", Vitória Regina Petters Gregório", Alacoque Lorenzini Erdmann'}

' Federal University of Santa Catarina, Postgraduate Program in Nursing. Florianópolis, Santa Catarina, Brazil. "Federal University of Santa Catarina, Health Science Center, Department of Nursing. Florianópolis, Santa Catarina, Brazil.

\section{How to cite this article:}

Copelli FHS, Oliveira RJT, Santos JLG, Magalhães ALP, Gregório VRP, Erdmann AL. Care management and nursing governance in a maternity ward: grounded theory. Rev Bras Enferm [Internet]. 2017;70(6):1277-83.

DOI: http://dx.doi.org/10.1590/0034-7167-2016-0116

Submission: 04-03-2016 Approval: 02-10-2017

\begin{abstract}
Objective: To understand the care management strategies used by nurses in the governance of nursing practice in a maternity ward. Method: Qualitative study based on grounded theory conducted with 27 participants, partitioned into four sample groups. The data were collected through semi-structured interviews and analyzed through open, axial, and selective coding. Result: The care management strategies used by the nurses were: planning professional practice, leading the nursing team, search for scientific knowledge, and training inthe best practices in obstetric care. Conclusion: Associating care management with nursing governance can foster better care outcomes and strengthen nursing autonomy when coordinating nursing work in maternity wards.
\end{abstract}

Descriptors: Management; Nursing Care; Nursing Supervision; Obstetric Nursing; Research About Nursing Administration.

\section{RESUMO}

Objetivo: Compreender as estratégias de gerência do cuidado utilizadas pelos enfermeiros para a governança da prática de enfermagem em uma maternidade. Método: Pesquisa qualitativa do tipo Teoria Fundamentada nos Dados, realizada com 27 participantes, divididos em quatro grupos amostrais. Os dados foram coletados por meio de entrevistas semiestruturadas e analisados mediante codificação aberta, axial e seletiva. Resultado: As estratégias de gerência do cuidado utilizadas pelos enfermeiros identificadas foram o planejamento da prática profissional, a liderança da equipe de enfermagem, a busca do conhecimento científico e a realização de capacitações sobre melhores práticas no cuidado obstétrico. Conclusão: A articulação entre gerência do cuidado e governança de enfermagem pode propiciar melhores resultados assistenciais e potencializar a autonomia do enfermeiro na coordenação do trabalho de enfermagem em uma maternidade.

Descritores: Gerência; Cuidados de Enfermagem; Supervisão de Enfermagem; Enfermagem Obstétrica; Pesquisa em Administração de Enfermagem.

\section{RESUMEN}

Objetivo: Comprender las estrategias de administración del cuidado utilizadas por los enfermeros para la gobernanza de la práctica de enfermería en una maternidad. Método: Investigación cualitativa del tipo Teoría Fundamentada en los Datos, realizada con 25 participantes, divididos en cuatro grupos muestrales. Los datos fueron recogidos a través de entrevistas semiestructuradas, y analizados mediante codificación abierta, axial y selectiva. Resultados: Las estrategias de administración del cuidado utilizadas por los enfermeros que fueron identificadas fueron: planificación de la práctica profesional, liderazgo del equipo de enfermería, búsqueda del conocimiento científico, y realización de capacitaciones acerca de mejores prácticas en el cuidado obstétrico. Conclusión: 
La articulación entre administración del cuidado y gobernanza de enfermería puede facilitar mejores resultados asistenciales y potenciar la autonomía del enfermero en la coordinación del trabajo de enfermería en una maternidad.

Descriptores: Organización y Administración; Atención de Enfermería; Supervisión de Enfermería; Enfermería Obstétrica; Investigación en Administración de Enfermería.

CORRESPONDING AUTHOR José Luís Guedes dos SantosＥ-mail: jose.santos@ufsc.br

\section{INTRODUCTION}

Care management is one of the main anchors of professional nursing practice in health services, as it encompasses the relationship between the care and management dimensions of nursing work. The care dimension focuses on providing comprehensive care to meet thenursing needs of patients, while the management dimension consists of work organization and the technical management tools, such as staff sizing, planning, continuing development, supervision, and performance assessment. These instruments are employed with the goal of creating and implementing suitable conditions for care provision and to enhance the performance of nursing teams ${ }^{(1-2)}$.

In maternity wards, care management aims to facilitate the nursing care provided to mothers, newborns, and family members. Both in this context and in other care units, management tools contribute to organizing, planning, coordinating, delegating, or providing care, supervising, predicting, and providing resources, team training, developing educational measures with family members, interacting with other professionals, and occupying coordination and negotiation spaces, which allows for the implementation of care improvements ${ }^{(3)}$.

Maternity ward nurses have the potential to coordinate the complex services of obstetric care, especially nursing services, as they have the technical competence for such professional practice. However, nursing professionals are still politically weak, which limits professional autonomy and often results in subordination to other professional categories ${ }^{(4-5)}$.

To expand the margins of nursing professional autonomy in health services, one of the strategies used in the international context is the implementation of governance models. Governance is a new model for organizing health services and nursing relative to the processes that increase nurses' autonomy, control, and authority over their practice within health organizations or service, with the goal of improving quality of care ${ }^{(6)}$.

Models based on shared and/or participatory management promotes the development of professional autonomy, satisfaction with the work environment, and greater professional commitment to organizations. Shared governance is a type of governance that is especially present in health organizations and nursing. It consists of a decentralized approach that promotes the active participation of nurses in decision-making processes, lending them greater autonomy and control over the work environment. It also fosters quality of care and patient safety ${ }^{(6-7)}$.

Thus, nursing shared governance is based on shared decision-making, which considers partnership, equity, participation, and co-responsibility for actions ${ }^{(8)}$. Furthermore, shared governance contributes to professional nursing practice because it helps reach organizational objectives in health, such as positive patient care outcomes and increased work satisfaction, productivity, and nurse retention. It also provides nurses with greater autonomy and professional empowerment ${ }^{(9)}$.

In maternity wards, like in other health services, governance of professional nursing practice can be strengthened through care management, which is one of the main responsibilities of nurses. However, there is a paucity of scientific literature investigating care management strategies used to obtain governance over professional nursing practice, or proactive nursing practice that achieves the objectives of both the profession and the institution relative to care excellence and the effectiveness of management practices. Thus, the following research question was formulated: What care management strategies are adopted by nurses to obtain nursing governance in maternity wards? The objective of the present study was to understand the care management strategies used by nurses to obtain governance of nursing practices in a maternity ward.

\section{METHOD}

\section{Ethical aspects}

This study was approved by the Ethics Committee for Research with Human Subjects of the Federal University of Santa Catarina (CEP/UFSC). All participants signed a free and informed consent form and the study abided by national and international ethical precepts and Resolution 466/2012 of the Brazilian National Health Council. Participants were ensured anonymity through code names composed of the letter " $\mathrm{N}$ " for nurse, followed by the number indicating the order in which the interview was conducted.

\section{Study design}

This was a qualitative study based on grounded theory (GT) as its methodological framework ${ }^{(10)}$.

\section{Study setting}

The study was conducted in a maternity ward at a public university hospital in the South region of Brazil. It is nationally-recognized center of excellence in obstetric care because of its work to promote the philosophy of humanized birth care. The ward is divided into four sectors: obstetric/gynecological screening, the obstetric center (OC), shared accommodation, and the neonatal intensive care unit.

\section{Source of data}

The participants were divided into four sample groups (SG). The researchers intentionally assembled SG 1 with participants with experience with the investigated theme. The other groups emerged based on the data analysis of the previous sample groups. Thus, SG 1 (N1-N8) consisted of eight OC nurses, SG 2 (N9-N15) had seven nurses from the obstetric/gynecological screening and 
OC sectors, SG 3 (N16-N21) had six health team professionals, three of which were nursing technicians, one nursing aid, and two obstetric/gynecological medical residents. Finally, SG 4 (N22N27) consisted of six nurse managersat the studied hospital. Thus, according to the methodological precepts of GT, the sample size was determined by theoretical data saturation, with 27 interviews. It is worth mentioning that participants were selected based on the following inclusion criteria: availability and a minimum experience of three months in the sector. Exclusion criteria included being on leave of absence from work of any kind. No participant was excluded.

\section{Data collection and organization}

Data were collected through individual semi-structured interviews, conducted in-person in a private room in the participant's work place or home, recorded on a digital device. The interviews were conducted between January and May 2013. The guiding questions focused on the care management strategies used by the nurses and their relationship with the governance of professional nursing practice. The interviews were fully transcribed and lasted an average of 50 minutes each.

\section{Data analysis}

Data collection and analysis were conducted simultaneously. Data investigation was conducted manually, through the comparative analysis method, and coding was developed in three phases: open, axial, and selective coding ${ }^{(10)}$. Open coding consisted of separating, examining, comparing, and conceptualizing the data obtained. In this phase, the data were analyzed line by line, and the answers given by the participants were coded, and then grouped by similarities and differences. These code groupings composed the subcategories, labeled according to their corresponding theme. In axial coding, the data were grouped once more, giving rise to categories. In the last phase, or selective coding, the core category was found and developed, based on the paradigmatic model, which establishes an explanatory relationship between categories and subcategories ${ }^{(10)}$. Based on this process, the following core category or phenomenon emerged: "Governance emerging from professional nursing practice anchored in the exercise of control over the obstetric center care environment and in the mastery of scientific knowledge and professional experience," which consisted of 10 categories. This article presents the results of one of these categories: "Care management as a strategy for the governance of professional nursing practice."

\section{RESULTS}

The category "care management as a strategy for the governance of professional nursing practice" represents the strategies found in the study, which were subdivided into three subcategories: planning professional practice, leading the nursing team, and appropriating scientific knowledge and sharing it with the nursing team. The interconnection between category and subcategories is illustrated in Figure 1. Each subcategory is presented in detail in the next section.

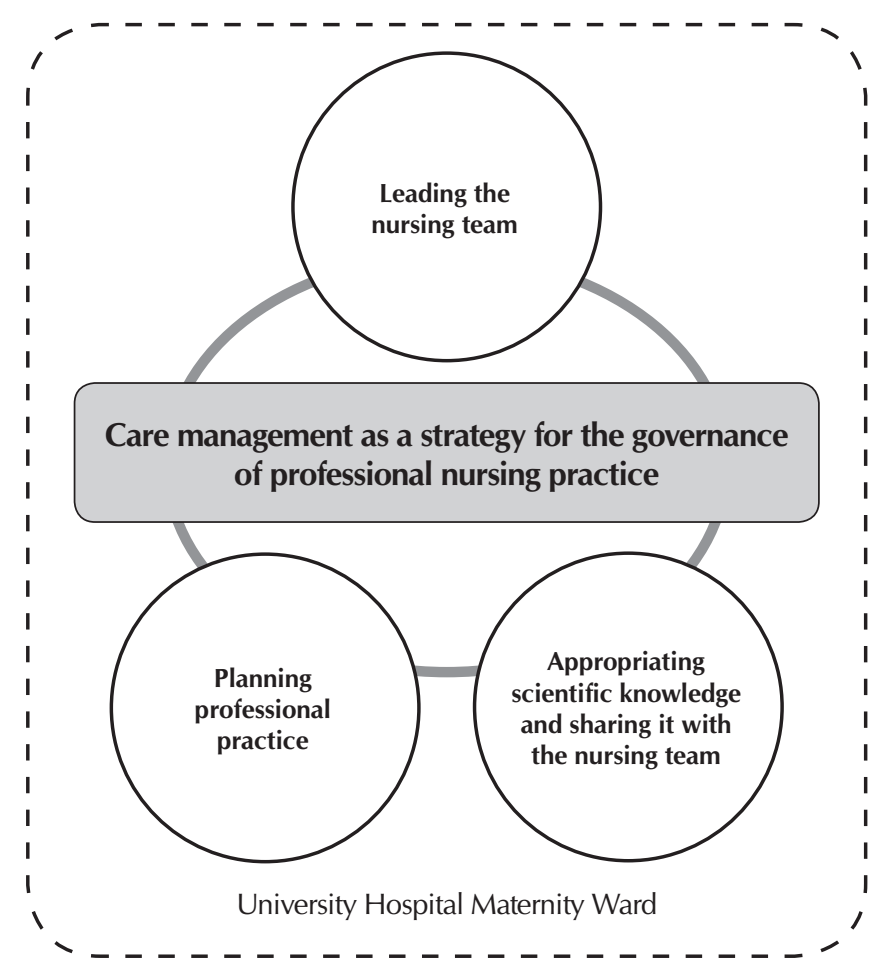

Figure 1 - Graphic representation of the strategies that favor governance over professional nursing practice

\section{Planning professional practice}

Planning is an essential strategy in organizing nursing care. Nurses in this study planned using three main interrelated actions: creating an assignment schedule, conducting handoffs, and performing visits. The assignment schedule served to define the activities assigned to each professional during their work shift. In order to list and define what is expected from each worker, nurses used information learned from handoffs. Nurses also visitedpatient rooms, talking with themand identifying the care needs that require the nursing staff's attention. Through these three activities, nurses gained an overall view of the sector, which granted them control over the environment for care management.

I make a little afternoon schedule, when I usually have three staff members. So, I put two here in gynecology and one outside working emergencies...I visit every room, talk to the patients, and see what I can do for them, i.e., I work out the plan for the afternoon. (N11)

By the time lget here and take on the night shift, I already have a good idea of what I have to do. (N1)

To plan care, nurses conducted diagnoses and analyzed the characteristics of the unit and of the nursing team. They outlined the care provided, became familiar with the most commonly performed procedures, and identified the strong points and weak points of staff members work abilities, thus contributing to the organization of care.

It's important to be familiar with the service and to know what are our unit's demands, what resources we have, what 
type of patients we care for, what type of procedures we perform. It's also important to be familiar with the limitations of each professional... some staff members find venous punctures challenging, so if there's a patient with weak vein walls and another professional does it better [venous punctures], you can go ask them if they can do it. But for this to happen you need to be familiar with the service, you have to know the team. (N9)

Another resource used by nurses to carry out planning was to hold work team meetings. The participants highlighted these meetings as a space for collective strengthening, where everyone can express their point of view about situations experienced in the everyday professional routine. Furthermore, another strategy was to conduct meetings together with professionals from other sectors, which provides an understanding of what occurs in related services, which is aligned with the search for joint problem-solving and integration among nurses.

There are some situations that we have to plan for... Ever since I started at the University Hospital, we have sought to strengthen the team through meetings, planning... I think it's the best strategy for nurses to position themselves. (N5)

Based on joint meetings, we have a better understanding of the situation in each sector... I think this [joint meetings with other sectors] could be better developed if all the heads of the maternity ward could hold more meetings with all of us together, permeating and mediating our teamwork, the integration among all in the maternity ward. (N13)

However, things do not always go according to plan. Increased patient demands in the maternity ward and the high staff absenteeism rates were some of the challenges mentioned by the nurses not only in planning, but also in carrying out care. To handle unforeseen events, the nurses strived to keep an organized environment, ensuring that sufficient amounts of materials and that devices are in working order. This ensures continuity of care, even when planning must be revisited.

It's hard to have control over everything when care demand is high, and you have to do many, many, things that you did not plan for. (N3)

I'm someone who likes to organize what I have to do [to have control]. But how am I going to be able to care for a newborn with four staff members? I need six on my team and I have four. There has to be continuity, everything has to be very well organized so that the next one who takes over can provide quality care. Everything in its place, materials replaced, and equipment in working order. This assessment ensures control.(N5)

When planning decisions, our work is participatory. So, we give staff members this liberty, but sometimes not all of them use it. (N24)

\section{Leading the nursing team}

Leadership is a nursing duty, as they are responsible for work organization, team coordination, and problem-solving.
Thus, they must also work as staff motivators and coordinators of teamwork. For example, when staff members were not willing to help co-workers, the studied nurses reportedusingstrategies that reinforce the need for mutual help.

You are the team leader. They [the team] depend quite a lot on nurses. You have to solve problems. This is what I always tell myself, there has to be a solution. (N1)

As in all large groups, I think you have to have a mind for leadership... A leader is needed to avoid making a mess.(N17)

Nurses need to take a stand... It's very challenging when there's no high-level leader to say... Let's work together on this and that (N21)

Taking on a leadership role is a natural consequence of nursing responsibilities related to care management and promoting teamwork. However, not all nurses are clear on the importance of leadership in their context of professional practice. Coupled with leadership, there is also the communicative dimension of nursing practice. Communication helps establish a dialogical relationship with the nursing team, which is essential to governance of professional nursing practice.

We have observed how nurses are unaware of their leadership role, they don't realize this dialogical role in work relationships. (N13)

We [nurses] are leaders, educators, caregivers... Nurses who do not understand that our first duty is to lead will find the work very challenging... You have to be a leader. I don't like this distance[from technicians] because I'm a leader and can't get close, much to the contrary, I think it's important for us to dialogue with everyone. (N6)

I think governance for me involves this issue of being a leader, talking to people, relating to people. (N26)

\section{Appropriating scientific knowledge and sharing it with the nursing team}

To manage care and obtain governance over professional nursing practice in the maternity ward, another strategy used by the nurses was to search for scientific knowledge, both for themselves and for sharing with the team. The search for knowledge through professional training and refresher courses strengthens nursing competencies and skills, which results in greater recognition and autonomy in their practice.

When you're a nurse and you have the technical and scientific capacity, the dexterity to do things, nobody will ever question you; no other professional, whether physicians, psychologists or physical therapists, will meddle with your work. (N3)

Scientific knowledge is one way of being respected... (N6)

When I say "safety" I mean safety of knowledge, seeking out training to improve that which you feel needs improvement...This is a must for professionals who want to be recognized at work. (N13) 
During our shift, we have complete autonomy; of course, within my sphere of competence and knowledge... (N8)

Scientific knowledge also gave nurses greater safety when making clinical and managerial decisions in the context of the maternity ward. The decision-making process was based on knowledge that sustains governance over nursing practice.

I base my decisions on knowledge. We need to know what we are deciding. There's no point in wanting to make decisions if you're not sure if that's the best decision to be made. So, you have to study a lot. (N5)

It's no use wanting to make decisions with no knowledge or consistency in what you're saying. (N5)

I always seek to care for and assist patients in the best possible way, obviously based on all the technical-scientific principles, striving to be as evidence-based as possible. (N22)

In addition to seeking their own professional development, nurses also promoted training activities with the goal of achieving the best obstetric care practices. To this end, nurses mainly usedthe clinical cases that emerged during the work routine and discussed them with the nursing team. They also shared the new things they have learned in conferences and scientific eventswith their peers.

Knowledge shouldn't just stay with you, it has to be propagated so that we can achieve better care...We [the nursing team] are always sitting down together and discussing things. Every time a patient is admitted with a given condition, I explain the situation saying "this patient is in this condition because of this". (N4)

Every time I learn a new thing, I sit down and talk to them [nursing technicians]... I explain some of the situations I have seen giong on, I explain to them the physiology, what could have been done differently. So, when I go to conferences, evetns, I share what I learned with my team... (N6)

\section{DISCUSSION}

Planning created the foundation for nurses to obtain governance of nursing practice, consisting of assignment schedules, handoffs, and nurse visits. Similarly, previous studies have also emphasized the importance of handoffs in organizing and planning nursing team activities, in addition to guiding nursing visits and interventions ${ }^{(11-13)}$.

Another care management strategy mentioned by the participants was being familiar with the dynamics of each sector, and the strong and weak points of staff members, which was also found in another study that investigated the experiences of a nursing team with leadership. Respect, dynamicity, and fluidity in work activities requires that nurses, nursing team leaders, be familiar and understand the duties of each member, in addition to the context in which they are inserted ${ }^{(14)}$

In the studied maternity ward, planning included some specificities to strengthen nursing governance, such as team meetings, as these help empower nurses involved in the work dynamics. It is worth emphasizing the importance of nurses in conducting meetings that facilitate understanding and synergy among the team, so that such moments of collective discussion contribute to the social development of the group involved in professional nursing practice planning ${ }^{(15)}$.

Regular meetings with the team is understood as a strategy that facilitates the adoption of dialogical and participatory leadership in the hospital environment, as it is a time for sharing knowledge, reflection, and when professionals come closer together ${ }^{(16)}$

Increased patient demand and the high level of staff absenteeism posed challenges to planning in the maternity ward. However, the assessment and re-planning of actions were strategies used to maintain control before challenges and ensure governance of professional nursing practice. Control over the work environment is necessary for the development of adequate care practices. Thus, indicators must be developed to assess the quality of such care, such as those relative to personnel management.

Quanti-qualitative assessment of nursing staff is considered an essential indicator for nursing management, as it directly impacts the humanization of care, resource optimization, and health care costs, in addition to providing quality care to meet patient demands ${ }^{(17-18)}$. Assessing the situation based on indicatorsof staff sizing, re-planning actions, and nursing interventionsare essential conditions to maintain quality of care.

In the context of the work organization in the studied maternity ward, nursing leadership emerged as a necessary skill to implement care management. In this setting, nurses exercised governance because they lead teams, coordinated work and solved problems. Based on the results of this study, it can be said that the nurses adopted a participatory leadership approach, reflected by teamwork and mutual help. Similar results have been found in the literature, since head nurses and nursing team leaders are expected to integrate teams to carry out activities and favor a healthy work environment, establishing bonds of trust, and minimizing conflict. Furthermore, nurse leaderships must share leadership with their teams by developing activities, constructing routines or even solving problems together as a group ${ }^{(19)}$.

Despite the importance of leadership skills for nurses, some do not recognize the importance of leadership in their professional practice. This can result in difficulties in communication and relationship with the team, who expects nurses to take the leading role. Communication is an essential tool for leadership, as it helps makes the leader-follower relationship more flexible and distances leaders from a controlling and rule-dictating role. Thus, leaders must be willing not only to talk, but also to listen to those under them, who expect to receive guidelines from their conductors ${ }^{(14)}$.

Regarding the search for scientific knowledge, the results also showed that the nurses recognized the value of training and refresher courses that enable them to exercise their profession with autonomy and safety. In the professional development process, it is important that nurses keep up to date and expand their skills and knowledge ${ }^{(20)}$.

Autonomy was seen as a personal construction of nurses in the work context of the maternity ward. The more they expanded their margins of autonomy, the greater the responsibility they felt 
in relation to care management to ensure governance over professional nursing practice, which corroborates previous research about the factors involved in care management ${ }^{(21)}$.

Training the nursing staff to perform the best practices in obstetric care can be considered a continuing development activity. Such training involved unscheduled activities based on doubts or novelties that emerged in the work context and that occurred in group conversations and discussions. This proactive attitude shows the potential of nurses to incentivize and promote transformations in health care practices ${ }^{(18)}$. Furthermore, as shown by a study about the clinical competencies of bedside nurses in the hospital environment, nurses, in the position of group coordinators, must foster spaces for the integration of thinking, feeling and action in nursing practice ${ }^{(19)}$.

Continuing development is based on asking questions about professional practice and on the assumption that learning occurs through action-reflection-action. Therefore, it is different from continuing education, which is based on one-off, fragmented actions, based on traditional teaching methodologies ${ }^{(22)}$. In the studied context, the formalization and maintenance of spaces forcontinuing development was important to the valorization of nursing professionals and to encourage learning at work.

\section{Limitations of the study}

The results of this study are limited to a specialized service, thus preventing its generalization to other care scenarios. Furthermore, the literature review was based on studies about correlate themes, due to the limited number of investigations about the studied theme. It is important to point out that governance of professional nursing practice is still anincipient field of study in Brazil, with the need for further research in the different settings of nursing care.

\section{Contributions to the field of nursing}

The results showed that the theme of care management and shared governance can help understand the scenario of administration in nursing and propose new perspectives about how governance occurs, observing the strategies used to obtain it. Thus, this study contributed to the understanding of how care management and nursing governance are related in a maternity ward, which can provide the basis for achieving better care outcomes.

\section{CONCLUSION}

The care management strategies used by nurses to ensure governance of nursing practice in the studied maternity ward were: planning, leadership, and the search for scientific knowledge. Planning consisted of assignment schedules, shift handoffs, and nursing visits, which provided nurses with the conditions to exercise governance over nursing practice. In this scenario, leadership and the search for scientific knowledge strengthened nursing autonomy, and contributed to executing and coordinating work in the ward.

\section{REFERENCES}

1. Hausmann M, Peduzzi M. Articulação entre as dimensões gerencial e assistencial do processo de trabalho do enfermeiro. Texto Contexto Enferm [Internet]. 2009[cited 2016 Dec 19];18(2):258-65. Available from: http://www.scielo.br/pdf/tce/v18n2/08

2. Santos JLG, Pestana AL, Guerrero P, Meirelles BSH, Erdmann AL. Práticas de enfermeiros na gerência do cuidado em enfermagem e saúde: revisão integrativa. Rev Bras Enferm [Internet]. 2013[cited 2016 Dec 19];66(2):257-63. Available from: http://www.scielo. br/pdf/reben/v66n2/16.pdf

3. Maziero VG, Bernardes A, Spiri WC, Gabriel CS. Construindo significados sobre gerência da assistência: um estudo fenomenológico. Ciênc Cuid Saúde [Internet]. 2014[cited 2016 Dec 19];13(3):563-70. Available from: http://www.periodicos.uem.br/ojs/index. php/CiencCuidSaude/article/view/23245/pdf_230

4. Barbosa LR. Professional competences and the formation process in nursing: a integrative review. Rev Enferm UFPE [Internet]. 2015[cited 2016 Dec 19];9(supl.8):9393-8. Available from: http://www.revista.ufpe.br/revistaenfermagem/index.php/revista/ article/view/6522/pdf_8635

5. Sousa FMSA, Silva PRA, Mello MA, Benito LAO. Dificuldades enfrentadas por enfermeiros obstetras no desempenho de suas atividades laborais. Acta Ciênc Saúde [Internet]. 2012[cited 2016 Dec 19];2(1):68-86. Available from: http://www2.Is.edu.br/ actacs/index.php/ACTA/article/view/44/51

6. Bennett PN, Ockerby C, Begbie J, Chalmers C, Hess RG Jr, O'Connell B. Professional nursing governance in a large Australian health service. Contemp Nurse [Internet]. 2012[cited 2016 Dec 19];43(1):99-106. Available from: https://www.ncbi.nlm.nih.gov/ pubmed/23343238

7. Kutney-Lee A, Germack H, Hatfield L, Kelly S, Maguire P, Dierkes A, et al. Nurse engagement in shared governance and patient and nurse outcomes. J Nurs Adm [Internet]. 2016[cited 2016 Dec 19];46(11):605-12. Available from: https://www.ncbi.nlm.nih. gov/pubmed/27755212

8. Clavelle JT, O'Grady TP, Drenkard K. Structural empowerment and the nursing practice environment in Magnet ${ }^{\circledR}$ organizations. J Nurs Adm [Internet]. 2013[cited 2016 Dec 19];43(11):566-73. Available from: https://www.ncbi.nlm.nih.gov/pubmed/24153197

9. Wilson J, Speroni KG, Jones RA, Daniel MG. Exploring how nurses and managers perceive shared governance. Nurs [Internet]. 2014[cited 2016 Dec 19];44(7):19-22. Available from: https://www.ncbi.nlm.nih.gov/pubmed/24937613 
10. Strauss A, Corbin J. Pesquisa qualitativa: técnicas e procedimentos para o desenvolvimento da teoria fundamentada. 2.ed. Porto Alegre: Artmed; 2008.

11. Pereira BT, Brito CA, Pontes GC, Guimarães EMP. A passagem de plantão e a corrida de leito como instrumentos norteadores para o planejamento da assistência de enfermagem. REME Rev Min Enferm [Internet]. 2011[cited 2016 Dec 19];15(2):283-9. Available from: http://www.reme.org.br/artigo/detalhes/37

12. Rodriguez L, Oliveira EO, de França CS, de Andrade TRS, Campos JSPA, Silva MP, Costacurta FJ. Mapeamento da passagem de plantão sob a ótica dos profissionais de enfermagem. Enferm Glob [Internet]. 2013[cited 2016 Dec 19];12(31):206-31. Available from: http://scielo.isciii.es/pdf/eg/v12n31/pt_administracion4.pdf

13. Lanzoni GMM, Magalhães ALP, Costa VT, Erdmann AL, Andrade SR, Meirelles BHS. Tornando-se gerente de enfermagem na imbricada e complexa fronteira das dimensões assistencial e gerencial. Rev Eletr Enf [Internet]. 2015[cited 2016 Dec 19];17(2):32232. Available from: https://www.fen.ufg.br/revista/v17/n2/pdf/v17n2a16.pdf

14. Vieira TDP, Renovato RD, Sales CM. Compreensões de liderança pela equipe de enfermagem. Cogitare Enferm [Internet]. 2013[cited 2016 Dec 19];18(2):253-60. Available from: http://revistas.ufpr.br/cogitare/article/view/27706

15. Llapa-Rodriguez EO, Oliveira JKA, Lopes ND, Campos MPA. Avaliação da liderança dos enfermeiros por auxiliares e técnicos de enfermagem segundo o método 360. Rev Gaúcha Enferm [Internet]. 2015[cited 2016 Dec 19];36(4):29-36. Available from: http:// seer.ufrgs.br/index.php/RevistaGauchadeEnfermagem/article/view/50491/35656

16. Amestoy SC, Backes VMS, Thofehrn MB, Martini JG, Meirelles, BHS, Trindade LL. Liderança dialógica: estratégias para sua utilização no ambiente hospitalar. Invest Educac Enferm [Internet]. 2014[cited 2016 Dec 19];32(1):119-27. Available from: http:// www.scielo.br/pdf/reben/v63n5/25.pdf

17. Magalhães AMM, Riboldi CO, Guzinski C, Silva RC, Moura GMSS. Level of dependence among patients in a surgical unit. Rev Bras Enferm [Internet]. 2015[cited 2016 Dec 19];68(5):824-9. Available from: http://www.scielo.br/pdf/reben/v68n5/0034-7167reben-68-05-0824.pdf

18. Delgado BAS, Naranjo TME. El acto de cuidado de enfermería como fundamentación del quehacer profesional e investigativo. Av Enferm [Internet]. 2015[cited 2016 Dec 19];33(3):412-9. Available from: http://www.revistas.unal.edu.co/index.php/avenferm/ article/view/42015/54814

19. Aued GK, Bernardino E, Peres AM, Lacerda MR, Dallaire C, Ribas EA. Clinical competences of nursing assistants: a strategy for people management. Rev Bras Enferm [Internet]. 2016[cited 2016 Dec 19];69(1):142-9. Available from: http://www.scielo.br/pdf/ reben/v69n1/en_0034-7167-reben-69-01-0142.pdf

20. Moura GMSS, Inchauspe JAP, Dal'agnol CM, Magalhães AMM, Hoffmeister LV. Expectations of the nursing staff in relationship to leadership. Acta Paul Enferm [Internet]. 2013[cited 2016 Dec 19];26(2):198-204. Available from: http://www.scielo.br/pdf/ape/ v26n2/en_v26n2a15.pdf

21. Pool I, Poell R, Cate OT. Nurses' and managers' perceptions of continuing professional development for older and younger nurses: a focus group study. Int J Nurs Stud [Internet]. 2013[cited 2016 Dec 19];50(1):34-43. Available from: https://www.ncbi.nlm.nih. gov/pubmed/22944285

22. Miccas FL, Batista SHSS. Permanent education in health: a review. Rev Saúde Pública [Internet]. 2014[cited 2016 Dec 19];48(1):17085. Available from: http://www.scielo.br/pdf/rsp/v48n1/en_0034-8910-rsp-48-01-0170.pdf 